\title{
Latitude gradient influences the age of onset of rheumatoid arthritis : a worldwide survey
}

\section{Ramos-Remus, Cesar}

2017-03

Ramos-Remus , C , Barajas-Ochoa, A, Ramirez-Gomez , A, Castillo-Ortiz , J D , Brambila-Barba, V , Adebajo, A O , Espinoza , L R , Aceves-Avila , F J , Sanchez-Gonzalez , J M , Boudersa , N , Slimani , S, Ladjouze-Rezig , A, Diaz, M P , Kirmayr , K I, Asnal , C A , Catoggio , L J , Citera , G , Casado , G C , Alvarez , A P , Pisoni , C N , Benavente , E , Lopez-Cabanillas , A , Baez, R M , Pons-Estel, B A, Sacnun , M P , Cavallasca , J A, Paniego, R H , Proudman , S M , Thomas , R, Major, G , Mathers, D M , Schrieber , L , Islam , N , Haq , S A, Dessein , P H, von Muhlen , C A, Bianchi , W A , Castelar-Pinheiro, G D R, Feldman-Pollak, D, Cossermelli, W, Bonfiglioli , K R, Giorgi , R D , Zabsonre-Tiendrebeogo , W J , Olaru , L , Karsh , J , Castro-Esparza , I H , Fuentealba , C , Aguilera, S, Burgos , P I , Leirisalo-Repo , M \& GEO-RA Grp 2017 , ' Latitude gradient influences the age of onset of rheumatoid arthritis : a worldwide survey ', Clinical Rheumatology, vol. 36 , no. 3 , pp. 485-497 . https://doi.org/10.1007/s10067-016-3481-9

http://hdl.handle.net/10138/235604

https://doi.org/10.1007/s10067-016-3481-9

publishedVersion

Downloaded from Helda, University of Helsinki institutional repository.

This is an electronic reprint of the original article.

This reprint may differ from the original in pagination and typographic detail.

Please cite the original version. 


\title{
Latitude gradient influences the age of onset of rheumatoid arthritis: a worldwide survey
}

\author{
GEO-RA Group
}

Received: 10 October 2016 / Accepted: 7 November 2016/Published online: 19 December 2016

(C) International League of Associations for Rheumatology (ILAR) 2016

\begin{abstract}
The age of onset of rheumatoid arthritis (RA) is an important outcome predictor. Northern countries report an age of RA onset of around 50 years, but apparently, variability exists across different geographical regions. The objective of the present study is to assess whether the age of onset of RA varies across latitudes worldwide. In a proof-of-concept crosssectional worldwide survey, rheumatologists from preselected cities interviewed 20 consecutive RA patients regarding the date of RA onset (RAO, when the patient first noted a swollen joint). Other studied variables included location of each city, rheumatologist settings, latitudes $\left(10^{\circ}\right.$ increments, south to north), longitudes (three regions), intracountry consistency, and countries' Inequality-adjusted Human Development Index (IHDI). Data from 2481 patients ( $82 \%$ females) were obtained from 126 rheumatologists in 77 cities of 41 countries. Worldwide mean age of RAO was $44 \pm 14$ years $(95 \%$ CI $44-45)$. In $28 \%$ of patients, RA began before age 36 years and before age 46 years in $50 \%$ of patients. RAO was 8 years earlier around the Tropic of Cancer when compared with northern latitudes ( $p<0.001,95 \%$ CI 3.5-13). Multivariate analysis showed that females, western cities, and latitudes around the Tropic of Cancer are associated with younger age of RAO $\left(R^{2} 0.045, p<0.001\right)$. A positive correlation was found between the age of RAO and IHDI $(r=0.7, p<0.01$, $\left.R^{2} 0.5\right)$. RA often begins at an early age and onset varies across latitudes worldwide. We postulate that countries'
\end{abstract}

Electronic supplementary material The online version of this article (doi:10.1007/s10067-016-3481-9) contains supplementary material, which is available to authorized users.

GEO-RA Group

geo.ragroupstudy@gmail.com;

1 Unidad de Investigacion en Enfermedades Cronico-Degenerativas, Guadalajara, Mexico developmental status and their geographical and geomagnetic location influence the age of RAO.

Keywords Age of onset · Environmental .

Geoepidemiology $\cdot$ Inequality $\cdot$ Pollution $\cdot$ Rheumatoid arthritis

\section{Introduction}

Rheumatoid arthritis (RA) is a disease of unknown cause and variable clinical presentation. Its prevalence and incidence vary across populations [1-3] and time [4-6]. Patients with RA may have a variable course, and their response to treatment is oftentimes unpredictable. Because of this variability, RA has been described as one of modern medicine's greatest enigmas [7].

The complete etiologic picture of this disease remains unclear because the genetic contribution to RA has been estimated to be $12-60 \%[8,9]$, and environmental factors contribute to up to half of the variation in disease susceptibility [10]. Variations in the reported figures on genetic and environmental factors across populations can be partially explained by differences in study design, the time when studies were performed, and that the data often come from historical studies that are restricted to specific regions or ethnic groups. Nevertheless, it is recognized that there are differences in the rates of occurrence of RA between countries and areas of the world [3].

The age of RA onset (RAO) is recognized as one of the most important predictors of disease outcome [11]. When RA starts at an early age, the economic burden imposed upon the patient, their family, and health services may be devastating. However, variability in the age of RAO is often neglected in studies of RA patterns. Some reports involving patients of 
European descent from developed countries found that the mean age of RAO is around 50 years [2, 12-14] with epidemiologic studies from these countries consistently reporting incidence rates that increase with age into the 70s [1]. Conversely, some studies from African and Asian countries have observed a significantly earlier peak in the mean age of RAO, which can be as young as the 20s or 30s [1]. Significant variations in the age of RAO have been reported in regional studies at different latitude gradients, both in terms of the mean age of onset and the frequency distribution by age groups $[15,16]$.

Latitude gradients have been used in geoepidemiology as a surrogate to study the influence of environment on disease incidence and risks across different geographic areas, so as to generate hypotheses for further investigation [17]. For example, diseases such as systemic lupus erythematosus, dermatomyositis, and Crohn's disease are geographically associated with northern latitudes [17].

The objective of this proof-of-concept cross-sectional survey was to assess whether the age of RAO varies across latitudes worldwide.

\section{Subjects and methods}

In a proof-of-concept survey, rheumatologists working at preselected cities around the world interviewed consecutive RA patients regarding their disease onset. Major cities were selected by $15^{\circ}$ quadrants (latitude and longitude) worldwide. Rheumatologist contact information for these cities was obtained using regional or local rheumatology association open databases, the web site of the US National Library of Medicine (PubMed), and direct recommendation from selected rheumatologists. An individualized invitation letter, which included information about the study but not its hypothesis, was sent electronically to each identified rheumatologist. A reply confirming the rheumatologists' interest in participating and confirmation of whether they treated RA patients and were board certified in rheumatology, the type of clinical practice (private, university, or other), and the city and country where the rheumatologist worked was requested. No compensation was offered. A second electronic communication, with detailed instructions that included guidelines on how to gather patient information in the data log sheet format, was sent to rheumatologists who agreed to participate. Participants were to provide data by directly interviewing 20 consecutive RA patients as per the 1987 criteria of the American Rheumatism Association [18]. This information was limited to nonsensitive data, in compliance with local regulations, and included nontraceable patient identification (e.g., consecutive numbers, letters, or initials), date of birth (month and year), sex, date of RA diagnosis (month and year), and date of RAO, defined as the month and year when the patient first noticed a swollen joint.

Data from data log sheets were extracted by two medical students, and the precise latitude and longitude of each city were obtained using Google Earth (Google Inc., Mountain View, CA, USA). For cases in which the data $\log$ sheet included errors or inconsistencies for up to three patients, the participating rheumatologist was asked to review the data. If there were four or more patients with inconsistent data or submitted data from less than 18 patients, the complete set was excluded; no substitutions were allowed. Summary data and manuscript drafts were shared with all participants.

\section{Statistical analysis}

Data handling was based on the following assumptions: (a) rheumatologists would have easy access to $20 \mathrm{RA}$ patients in their clinical practice over a short period of time, to assure their compliance; (b) comparing data from two or more rheumatologists in the same city would allow us to assess the intracity consistency of the main variable (age of RAO) using nonparametric Mann-Whitney $U$ or Kruskal-Wallis tests; and (c) comparing data from two or more cities located at the same latitude in each country would allow us to assess intracountry consistency of the main variable using parametric tests (Student's $t$ test or one-way ANOVA). The age of RAO was examined as both a continuous variable and a categorical variable (age groups, 10-year increments).

Differences in age of RAO according to latitudes worldwide $\left(10^{\circ}\right.$ increments, south to north) were examined using one-way ANOVA for continuous variables (with a post hoc Schaffé for multiple comparisons), whereas a Pearson's chi-square or Fisher's exact test was used for categorical variables. Thereafter, the world map was arbitrarily divided by longitudes into three regions: region 1 $\left(30^{\circ} \mathrm{W}\right.$ to $\left.134^{\circ} \mathrm{W}\right)$ that includes countries of the Americas; region $2\left(29^{\circ} \mathrm{W}\right.$ to $\left.104^{\circ} \mathrm{E}\right)$ that includes countries of Europe, Africa, and Western Asia; and region 3 $\left(105^{\circ} \mathrm{E}\right.$ to $\left.180^{\circ} \mathrm{E}\right)$ that includes countries of East Asia and Oceania. This division was made to assess whether significant differences in the age of RAO, detected according to latitudes worldwide, persisted by region (using oneway ANOVA and Pearson's chi-square or Fisher's exact test). A $p$ of $\leq 0.05$ was set as the level of statistical significance, and confidence intervals were reported at 95\% (95\% CI).

Stepwise multiple linear regression analysis was performed to assess the effects of sex (binary), northern cities (binary), western cities (binary, from the Greenwich parallel), cities 
grouped per longitude (categorical variable, three regions), and cities grouped per latitude code (categorical variable, each $10^{\circ}$ ) on age of RAO. A backward regression was run for all significant variables $(p<0.1)$ identified by univariate analysis.

After reviewing the results, a post hoc analysis was performed to explore whether the age of RAO is correlated with the developmental status of participating countries (Pearson's correlation coefficient). The countries' developmental status was obtained from the United Nations Development Programme report [19] on the 2015 Human Development Index (HDI) (years 2010-2014) and on the Inequalityadjusted HDI (year 2014).

This being a nonintervention study, and the collected information precludes individual patient identification (nonsensitive data), no informed consent was required as per local regulations at each site.

\section{Results}

Figure 1 shows the distribution of rheumatologists invited to participate and those who accepted our invitation. Figure 2

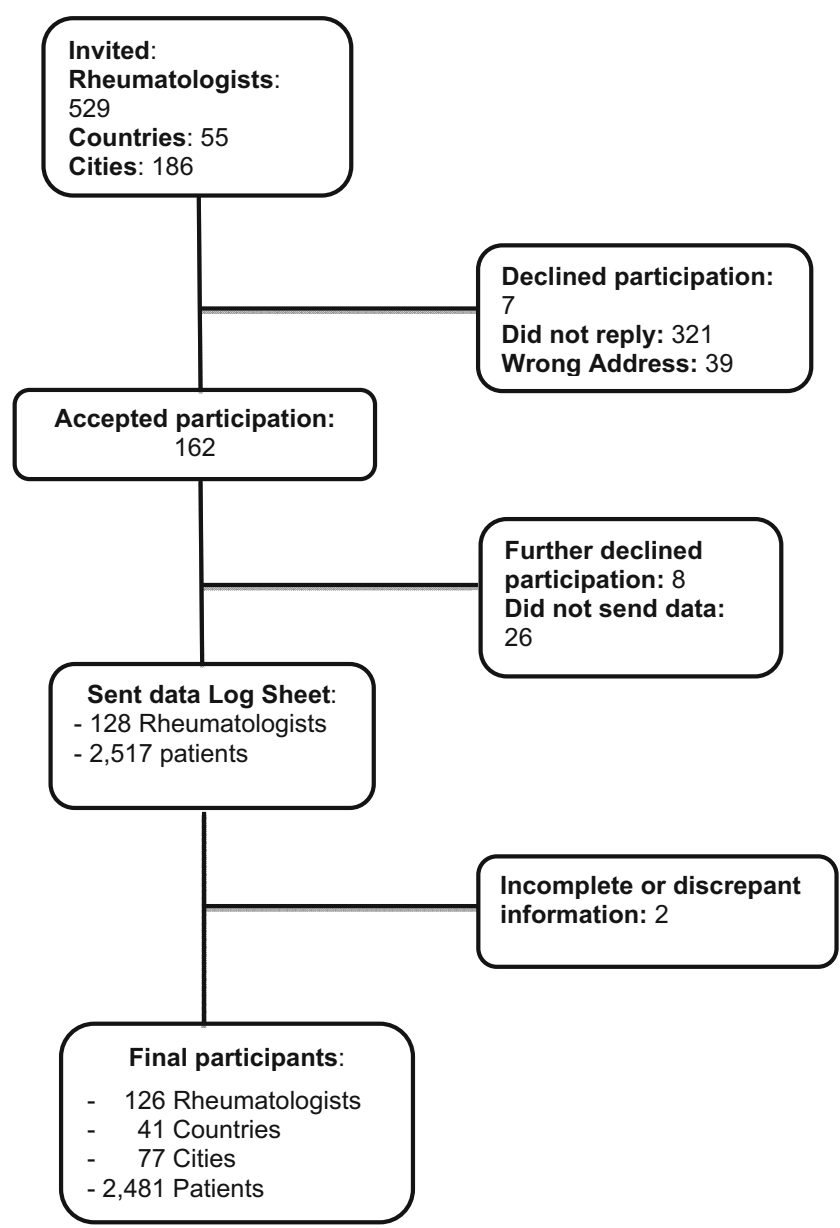

Fig. 1 Flow chart of study participants (rheumatologists, countries, and cities) shows the distribution of the mean age of RAO by participating country, with the number of sites (rheumatologists) and cities per country. We obtained data of 2481 patients $(82 \%$ females) from 126 rheumatologists in 77 cities of 41 countries.

Table 1 shows the mean age of RAO and the frequency distribution by age group according to latitude in $10^{\circ}$ intervals from south to north. The worldwide overall mean age of RAO was $44.4 \pm 14$ years (95\% CI 44-45). The overall frequency distribution by age group shows that $28 \%$ of patients had an RAO before the age of 36 years and between the ages of 16 and 45 years in $50 \%$ of patients. Analysis of age of RAO by latitude showed significant differences in both, as mean and as distribution by age groups. Age of RAO for latitude code 8 $\left(20^{\circ} \mathrm{N}\right.$ to $\left.29^{\circ} \mathrm{N}\right)$ was on average $8,8,5$, and 6 years younger when compared with latitude codes $11,10,3$, and 2 , respectively $(p<0.001,95 \%$ CI for differences of 3.5-13, 2-13, $0.1-10$, and $2-10$ years, respectively). Latitude codes 8 and 9 (around the Tropic of Cancer) had a higher proportion of patients with an RAO before age 35 years compared with northern or southern latitudes $(p<0.001)$. Intracity variability could be assessed in 29 (38\%) cities, and consistency was confirmed in $79 \%$ of them (supplementary Table 1). Intracountry variability could be assessed for $19(46 \%)$ countries, and consistency was ascertained in $16(84 \%)$ (supplementary Table 2).

The results of subanalysis by region (longitudes) are shown in Table 2 as the mean age of RAO and in Table 3 as the frequency distribution by age group, both by latitude in $10^{\circ}$ intervals south to north. Similar trends were observed in region 1 (the Americas), where 12 countries participated and provided data on a total of 1062 patients. No rheumatologists from the USA replied to our electronic communications. The overall mean age of RAO was $44 \pm 14$ years (95\% CI 43-45). Disease onset was on average 8 and 14.5 years younger for latitude code 8 compared with northern latitude codes 11 and 10 , respectively $(p<0.01)$, and 7 years younger than southern latitude code $2\left(31^{\circ}-40^{\circ} \mathrm{S}\right)(p=0.01)$. The frequency distribution by age group showed that in latitude code 8 , nearly half of patients had RAO before the age of 36 years, which was significantly different when compared with latitude codes $2(24.8 \%)$ and 6 $(27.8 \%)(p<0.001)$. In region 2 (Europe, Africa, and Western Asia), 24 countries participated, yielding data on 1126 total patients. The overall mean age of RAO was $44 \pm 14$ years $(95 \%$ CI $43-45)$. For latitude code 8 , RAO was on average 8.5 and 7.5 years younger when compared with northern latitude codes 11 and 10, respectively $(p<0.01)$. For latitude codes 8 and 9 , there were a significantly higher proportion of patients with RAO before age 36 years compared with latitudes 10 and $11(p=0.01)$. However, there is no land in latitude code $1\left(>40^{\circ} \mathrm{S}\right)$. In addition, in latitude code $4\left(11^{\circ} \mathrm{S}-\right.$ 


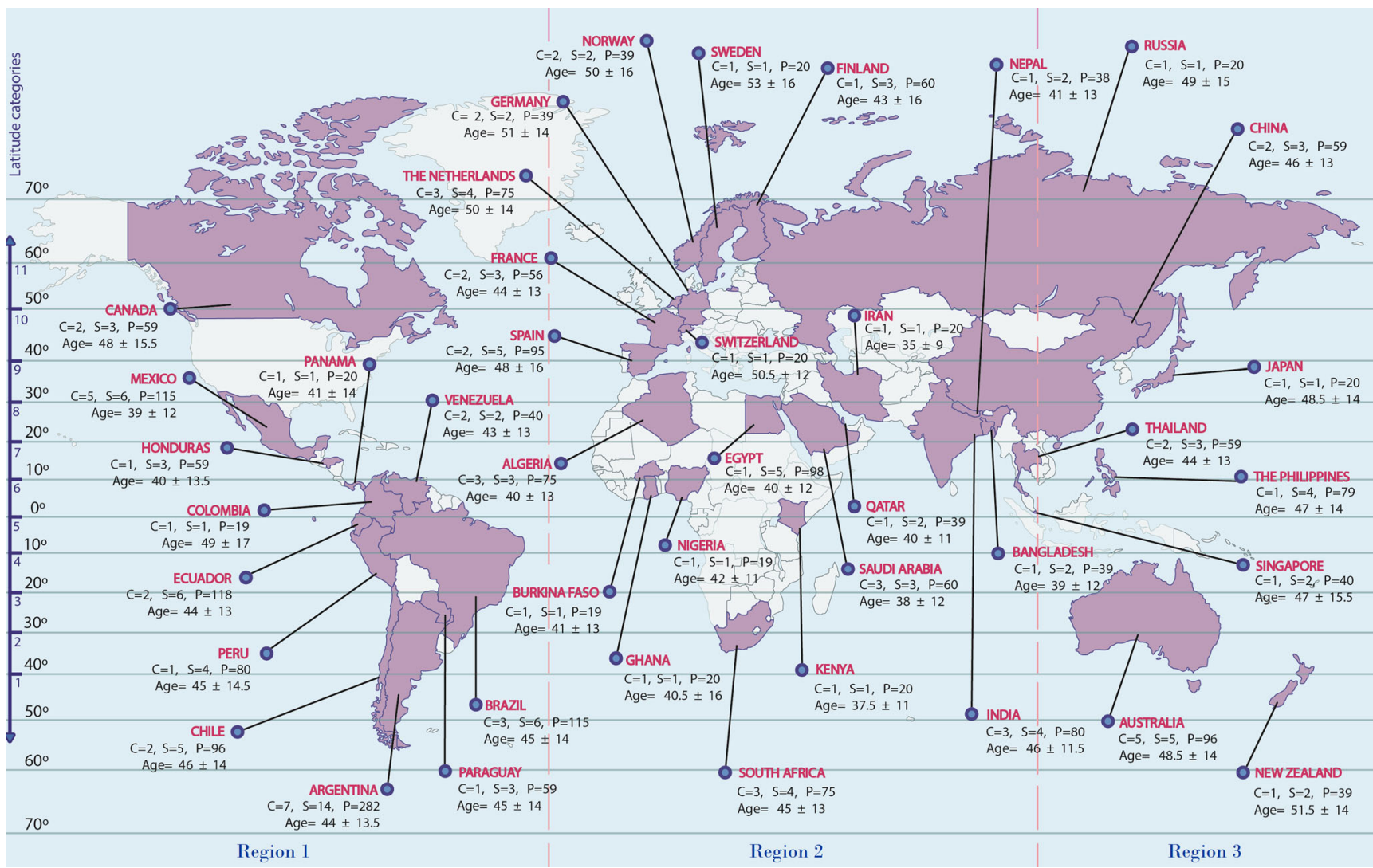

Fig. 2 Mean age of onset of rheumatoid arthritis distributed by participating country, number of cities $(C)$, number of sites $(S)$ (rheumatologists), and number of patients $(P)$

$20^{\circ} \mathrm{S}$ ), we were unable to contact rheumatologists in Senegal, Guinea, Niger, Ethiopia, and Sudan. The number of patients varied per country, yielding a broad $95 \%$
CI for latitude codes 3 and 5. In region 3 (East Asia and Oceania), five countries participated and provided data on 293 patients. We were unable to contact

Table 1 Worldwide distribution of mean age of onset of rheumatoid arthritis (RA) and frequency distribution by age group per every $10^{\circ}$ of latitude, south to north

\begin{tabular}{|c|c|c|c|c|c|c|c|c|}
\hline \multirow[t]{2}{*}{ Latitude, code (location) } & \multirow[t]{2}{*}{ Patients $N=$} & \multirow{2}{*}{$\begin{array}{l}\text { Age of onset of RA, } \\
\text { mean } \pm \text { SD (years) } \\
(95 \% \text { CI) }\end{array}$} & \multicolumn{6}{|c|}{ Age groups (years) $n(\%)^{* *}$} \\
\hline & & & $16-25$ & $26-35$ & $36-45$ & $46-55$ & $56-65$ & $>65$ \\
\hline $1\left(>40^{\circ} \mathrm{S}\right)$ & 96 & $45 \pm 14(42.5$ to 48$)$ & $4(4.2 \%)$ & $22(22.9 \%)$ & $23(24 \%)$ & $23(24 \%)$ & $13(13.5 \%)$ & $11(11.5 \%)$ \\
\hline $2\left(31^{\circ}\right.$ to $\left.40^{\circ} \mathrm{S}\right)$ & 473 & $46 \pm 14(44$ to 47$)$ & $32(6.8 \%)$ & $80(16.9 \%)$ & $125(26.4 \%)$ & $113(23.9 \%)$ & $84(17.8 \%)$ & $39(8.2 \%)$ \\
\hline $3\left(21^{\circ}\right.$ to $\left.30^{\circ} \mathrm{S}\right)$ & 213 & $45 \pm 14(43$ to 47$)$ & $19(8.9 \%)$ & $32(15 \%)$ & $50(23.5 \%)$ & $58(27.2 \%)$ & $37(17.4 \%)$ & $17(8 \%)$ \\
\hline $4\left(11^{\circ}\right.$ to $\left.20^{\circ} \mathrm{S}\right)$ & 80 & $45 \pm 14.5(41.5$ to 48$)$ & $8(10 \%)$ & $14(17.5 \%)$ & $16(20 \%)$ & $22(27.5 \%)$ & $12(15 \%)$ & $8(10 \%)$ \\
\hline $5\left(1^{\circ}\right.$ to $\left.10^{\circ} \mathrm{S}\right)$ & 138 & $43 \pm 13(41$ to 45$)$ & $15(10.9 \%)$ & $24(17.4 \%)$ & $34(24.6 \%)$ & $40(29 \%)$ & $19(13.8 \%)$ & $6(4.3 \%)$ \\
\hline $6\left(0^{\circ}\right.$ to $\left.9^{\circ} \mathrm{N}\right)$ & 158 & $44 \pm 15(42$ to 46.5$)$ & $21(13.3 \%)$ & $20(12.7 \%)$ & $40(25.3 \%)$ & $41(25.9 \%)$ & $24(15.2 \%)$ & $12(7.6 \%)$ \\
\hline $7\left(10^{\circ}\right.$ to $\left.19^{\circ} \mathrm{N}\right)$ & 316 & $44 \pm 13(42$ to 45$)$ & $33(10.4 \%)$ & $54(17.1 \%)$ & $61(19.3 \%)$ & $107(33.9 \%)$ & $49(15.5 \%)$ & $12(3.8 \%)$ \\
\hline $8\left(20^{\circ}\right.$ to $\left.29^{\circ} \mathrm{N}\right)$ & 389 & $40 \pm 12 *(39$ to 41$)$ & $41(10.5 \%)$ & $105(27 \%)$ & $104(26.7 \%)$ & $99(25.4 \%)$ & $29(7.5 \%)$ & $11(2.8 \%)$ \\
\hline $9\left(30^{\circ}\right.$ to $\left.39^{\circ} \mathrm{N}\right)$ & 193 & $43 \pm 15(41$ to 45$)$ & $18(9.3 \%)$ & $48(24.9 \%)$ & $43(22.3 \%)$ & $46(23.8 \%)$ & $22(11.4 \%)$ & $16(8.3 \%)$ \\
\hline $10\left(40^{\circ}\right.$ to $\left.49^{\circ} \mathrm{N}\right)$ & 153 & $48 \pm 14(45$ to 50$)$ & $6(3.9 \%)$ & $31(20.3 \%)$ & $30(19.6 \%)$ & $37(24.2 \%)$ & $30(19.6 \%)$ & $19(12.4 \%)$ \\
\hline $11\left(>50^{\circ} \mathrm{N}\right)$ & 272 & $48 \pm 15(46$ to 50$)$ & $18(6.6 \%)$ & $44(16.2 \%)$ & $52(19.1 \%)$ & $55(20.2 \%)$ & $63(23.2 \%)$ & $40(14.7 \%)$ \\
\hline Total & 2481 & $44 \pm 14(44$ to 45$)$ & $215(8.7 \%)$ & $474(19.1 \%)$ & $578(23.3 \%)$ & $641(25.8 \%)$ & $382(15.4 \%)$ & $191(7.7 \%)$ \\
\hline
\end{tabular}

*Latitude code 8 is significantly different compared with latitude codes $2,3,10$, and $11 ; p<0.001$

**Significant differences of age groups by latitudes, $p<0.001$ 
Table 2 Mean age of onset of rheumatoid arthritis (RA) by region (longitude), according to latitude

Regions by longitudes (longitude range) and participating countries

\begin{tabular}{|c|c|}
\hline Region $1\left(30^{\circ} \mathrm{W}\right.$ to $\left.134^{\circ} \mathrm{W}\right)$ & Region $2\left(29^{\circ} \mathrm{W}\right.$ to $\left.104^{\circ} \mathrm{E}\right)$ \\
\hline $\begin{array}{l}\text { Argentina, Brazil, Canada, Chile, Colombia, } \\
\text { Ecuador, Honduras, Mexico, Panama, } \\
\text { Paraguay, Peru, Venezuela }\end{array}$ & $\begin{array}{l}\text { Burkina Faso, Finland, France, Kenya, } \\
\text { Netherlands, Nigeria, Norway, Saudi Arabia, } \\
\text { South Africa, Spain, Sweden, Ghana, Russia, } \\
\text { Egypt, Algeria, Germany, Switzerland, Qatar, } \\
\text { Bangladesh, Iran, Singapore, Thailand, India, } \\
\text { Nepal }\end{array}$ \\
\hline
\end{tabular}

\begin{tabular}{|c|c|c|c|c|c|c|}
\hline \multirow[b]{2}{*}{ Latitude (range) } & & & \\
\hline & Patients $N=$ & $\begin{array}{l}\text { RA age of onset } \\
\text { Mean } \pm \text { SD }(95 \% \mathrm{CI})\end{array}$ & Patients $N=$ & $\begin{array}{l}\text { RA Age of onset } \\
\text { Mean } \pm \text { SD }(95 \% \text { CI })\end{array}$ & Patients $N=$ & $\begin{array}{l}\text { RA age of onset } \\
\text { Mean } \pm \text { SD }(95 \% \text { CI })\end{array}$ \\
\hline $1\left(>40^{\circ} \mathrm{S}\right)$ & 57 & $41 \pm 13(38$ to 44.5$)$ & - & - & 39 & $\begin{array}{l}51.5 \pm 14 \\
47 \text { to } 56\end{array}$ \\
\hline $2\left(31^{\circ}-40^{\circ} \mathrm{S}\right)$ & 339 & $45 \pm 14(44$ to 47$)$ & 57 & $\begin{array}{l}46 \pm 12 \\
43 \text { to } 49\end{array}$ & 77 & $\begin{array}{l}46.5 \pm 14 \\
43 \text { to } 50\end{array}$ \\
\hline $3\left(21^{\circ}-30^{\circ} \mathrm{S}\right)$ & 156 & $44 \pm 13(42$ to 46$)$ & 38 & $\begin{array}{l}43 \pm 13 \\
39 \text { to } 48\end{array}$ & 19 & $\begin{array}{l}57 \pm 11 \\
51 \text { to } 62\end{array}$ \\
\hline $4\left(11^{\circ}-20^{\circ} \mathrm{S}\right)$ & 80 & $45 \pm 14.5(41.5$ to 48$)$ & - & - & - & - \\
\hline $5\left(1^{\circ}-10^{\circ} \mathrm{S}\right)$ & 118 & $44 \pm 13(41$ to 46$)$ & 20 & $\begin{array}{l}37.5 \pm 11 \\
32 \text { to } 43\end{array}$ & - & - \\
\hline $6\left(0^{\circ}-9^{\circ} \mathrm{N}\right)$ & 79 & $44 \pm 14$ (41 to 47$)$ & 79 & $\begin{array}{l}44 \pm 15 \\
41 \text { to } 48\end{array}$ & - & - \\
\hline $7\left(10^{\circ}-19^{\circ} \mathrm{N}\right)$ & 98 & $41 \pm 13(38$ to 43$)$ & 139 & $\begin{array}{l}44 \pm 13 \\
42 \text { to } 46.5\end{array}$ & 79 & $\begin{array}{l}47 \pm 14 \\
44 \text { to } 50\end{array}$ \\
\hline $8\left(20^{\circ}-29^{\circ} \mathrm{N}\right)$ & 76 & $38 \pm 11.5(35$ to 40$)$ & 274 & $\begin{array}{l}39.5 \pm 12 \\
38 \text { to } 41\end{array}$ & 39 & $\begin{array}{l}46 \pm 13 \\
42 \text { to } 50.5\end{array}$ \\
\hline $9\left(30^{\circ}-39^{\circ} \mathrm{N}\right)$ & - & - & 153 & $\begin{array}{l}42 \pm 15 \\
40 \text { to } 44.5\end{array}$ & 40 & $\begin{array}{l}47 \pm 14 \\
42 \text { to } 51\end{array}$ \\
\hline $10\left(40^{\circ}-49^{\circ} \mathrm{N}\right)$ & 20 & $52.5 \pm 16(45$ to 60$)$ & 133 & $\begin{array}{l}47 \pm 14 \\
45 \text { to } 49\end{array}$ & - & - \\
\hline $11\left(>50^{\circ} \mathrm{N}\right)$ & 39 & $46 \pm 15(41$ to 51$)$ & 233 & $\begin{array}{l}48 \pm 15 \\
46 \text { to } 50\end{array}$ & - & - \\
\hline Total & 1062 & $44 \pm 14(43$ to 45$)$ & 1126 & $\begin{array}{l}44 \pm 14 \\
43 \text { to } 45\end{array}$ & 293 & $\begin{array}{l}48 \pm 14 \\
46 \text { to } 49.5\end{array}$ \\
\hline
\end{tabular}

rheumatologists in latitudes 4 to 6 (the Republic of Indonesia and Papua New Guinea) or latitudes 10 and 11 (the Kuril Islands and the Kamchatka Peninsula). No significant differences were found in this region for mean age of RAO and frequency distribution by age group, probably incurring in a type II error.

The final model in the stepwise multiple linear regression analysis included sex, latitude coded groups, and western cities. A significant regression equation was found ( $F$ (12, $2468)=9.72, p<0.001)$, with an $R^{2}$ of 0.045 . The age of RAO was significantly younger among females and patients from western cities; age of RAO was older at northern latitudes $\left(>50^{\circ} \mathrm{N}\right)$ (Table 4$)$. We did not find significant differences between other variables, such as rheumatologist practice type or the number of years in rheumatology practice.

Post hoc analysis showed a positive correlation $(r=0.58$, $p<0.0001)$ between the age of RAO and HDI by country for the years 2010 to 2014, with a coefficient of determination $\left(R^{2}\right)$ of 0.33 . When the HDI was adjusted for inequality (year $2014)$, the positive correlation became stronger $(r=0.71$, $p<0.01$ ), with an $R^{2}$ of 0.50 .

\section{Discussion}

Despite the importance of age of RAO as an outcome predictor, data on its variability in different populations are scarce and limited to specific geographical regions. In this proof-of-concept study, the age of RAO was evaluated in different regions of the world and its variability was analyzed per latitude gradients, as these are used as surrogates of environmental factors to posit hypotheses for further study. 
Table 3 Frequency distribution of age groups for onset of rheumatoid arthritis by region (longitude), according to latitude

Latitude codes ${ }^{\mathrm{a}}$

\begin{tabular}{llllllllllll}
\hline 1 & 2 & 3 & 4 & 5 & 6 & 7 & 8 & 9 & 10 & 11
\end{tabular}

Longitudes

Region $1\left(30^{\circ} \mathrm{W}\right.$ to $\left.134^{\circ} \mathrm{W}\right)$

Age groups, $n(\%)^{\mathrm{b}}$

\begin{tabular}{|c|c|c|c|c|c|c|c|c|c|c|c|}
\hline $16-25$ years & $4(7)$ & $24(7)$ & $15(10)$ & $8(10)$ & $12(10)$ & $8(10)$ & $12(12)$ & $9(12)$ & - & $1(5)$ & $3(8)$ \\
\hline 26-35 years & $18(32)$ & $60(18)$ & $25(16)$ & $14(17.5)$ & $19(16)$ & $14(18)$ & $23(23.5)$ & $25(33)$ & - & $3(15)$ & $7(18)$ \\
\hline $36-45$ years & $12(21)$ & $85(25)$ & $39(25)$ & $16(20)$ & 27 (23) & $21(27)$ & $23(23.5)$ & $20(26)$ & - & $2(10)$ & $9(23)$ \\
\hline $46-55$ years & $13(23)$ & $79(23)$ & $40(26)$ & $22(27.5)$ & $36(30.5)$ & $19(24)$ & $29(30)$ & $16(21)$ & - & $5(25)$ & $6(15)$ \\
\hline 56-65 years & $8(14)$ & $64(19)$ & $27(17)$ & $12(15)$ & $18(15)$ & $12(15)$ & $6(6)$ & $5(7)$ & - & $5(25)$ & $10(26$ \\
\hline$>65$ years & $2(3.5)$ & $27(8)$ & $10(6)$ & $8(10)$ & $6(5)$ & $5(6)$ & $5(5)$ & $1(1)$ & - & $4(20)$ & $4(10)$ \\
\hline tal & 57 & 339 & 156 & 80 & 118 & 79 & 98 & 76 & - & 20 & 39 \\
\hline
\end{tabular}

Region $2\left(29^{\circ} \mathrm{W}\right.$ to $\left.104^{\circ} \mathrm{E}\right)$

Age groups, $n(\%)^{\mathrm{b}}$

$\begin{array}{llllllllllll}\text { 16-25 years } & - & 4(7) & 4(10.5) & - & 3(15) & 13(16.5) & 14(10) & 31(11) & 16(10.5) & 5(4) & 15(6) \\ 26-35 \text { years } & - & 5(9) & 7(18) & - & 5(25) & 6(8) & 20(14) & 71(26) & 41(27) & 28(21) & 37(16) \\ 36-45 \text { years } & - & 19(33) & 8(21) & - & 7(35) & 19(24) & 27(19) & 78(28.5) & 32(21) & 28(21) & 43(18.5) \\ 46-55 \text { years } & - & 19(33) & 12(32) & - & 4(20) & 22(28) & 51(37) & 70(25.5) & 37(24) & 32(24) & 49(21) \\ 56-65 \text { years } & - & 7(12) & 6(16) & - & 1(5) & 12(15) & 24(17) & 18(7) & 14(9) & 25(19) & 53(23) \\ >65 \text { years } & - & 3(5) & 1(3) & - & 0(0) & 7(9) & 3(2) & 6(2) & 13(8.5) & 15(11) & 36(15.5) \\ \text { Total } & - & 57 & 38 & - & 20 & 79 & 139 & 274 & 153 & 133 & 233\end{array}$

Region $3\left(105^{\circ} \mathrm{E}\right.$ to $\left.180^{\circ} \mathrm{E}\right)$

Age groups, $n(\%)^{\mathrm{b}}$

\begin{tabular}{|c|c|c|c|c|c|c|c|c|c|c|c|}
\hline 16-25 years & $0(0)$ & $4(5)$ & $0(0)$ & - & - & - & $7(9)$ & $1(3)$ & $2(5)$ & - & - \\
\hline 26-35 years & $4(10)$ & $15(19.5)$ & $0(0)$ & - & - & - & $11(14)$ & $9(23)$ & $7(17.5)$ & - & - \\
\hline $36-45$ years & $11(28)$ & $21(27)$ & $3(16)$ & - & - & - & $11(14)$ & $6(15)$ & $11(27.5)$ & - & - \\
\hline 46-55 years & $10(26)$ & $15(19.5)$ & $6(32)$ & - & - & - & $27(34)$ & $13(33)$ & $9(22.5)$ & - & - \\
\hline 56-65 years & $5(13)$ & $13(17)$ & $4(21)$ & - & - & - & $19(24)$ & $6(15)$ & $8(20)$ & - & - \\
\hline$>65$ years & $9(23)$ & $9(12)$ & $6(32)$ & - & - & - & $4(5)$ & $4(10)$ & $3(7.5)$ & - & - \\
\hline Total & 39 & 77 & 19 & - & - & - & 79 & 39 & 40 & - & - \\
\hline
\end{tabular}

${ }^{a}$ Latitude codes: $1=>40^{\circ} \mathrm{S} ; 2=31^{\circ} \mathrm{S}-40^{\circ} \mathrm{S} ; 3=21^{\circ} \mathrm{S}-30^{\circ} \mathrm{S} ; 4=11^{\circ} \mathrm{S}-20^{\circ} \mathrm{S} ; 5=1^{\circ} \mathrm{S}-10^{\circ} \mathrm{S} ; 6=0^{\circ}-9^{\circ} \mathrm{N} ; 7=10^{\circ} \mathrm{N}-19^{\circ} \mathrm{N} ; 8=20^{\circ} \mathrm{N}-29^{\circ} \mathrm{N} ; 9=30^{\circ}$ $\mathrm{N}-39^{\circ} \mathrm{N} ; 10=40^{\circ} \mathrm{N}-49^{\circ} \mathrm{N} ;$ and $11=>50^{\circ} \mathrm{N}$

${ }^{\mathrm{b}}$ Rounded numbers

Our first important finding is that, in general, RA is not a disease of older adulthood. Based on the sample size of 2481 patients from 41 countries and the narrow $95 \%$ CI of the mean, we believe that our data are quite robust. The fact that half of RA patients worldwide have disease onset at a young age has several implications. First, RA may have a greater individual and familial impact than previously believed because its onset is before individuals reach their peak life roles. Second, the general perception that RA occurs mainly in older adulthood, which is based on older data from developed northern countries [1], may mislead local policy makers when allocating resources and developing health care strategies for a disease that can last as long as 40 years in many cases. Third, it is possible that the age of RAO has changed over the past five decades, together with temporal trends in the occurrence of RA [1, 4-6, 20-23].

Our second finding is that the age of RAO is significantly different along latitude gradients. We have shown that at latitudes around the Tropic of Cancer (latitude codes 8 and 9), RA starts at a younger age, with a higher proportion of patients developing the disease before age 36 years as compared with northern and southern latitudes. When analyzed by region (longitudes), similar trends were observed for region 1 . Region 2 also showed significant trends, but the data are not as robust as for the Americas. Region 3 lacked data at several latitudes, and the broad $95 \%$ CI observed for the available data indicates a possible type II error. However, multiple linear regression models showed that RA starts at a significantly 
Table 4 Stepwise linear regression, variables associated with age of onset of rheumatoid arthritis

\begin{tabular}{|c|c|c|c|c|}
\hline Variable & $\begin{array}{l}\text { Univariable } \beta \\
\text { coefficient } \\
95 \% \mathrm{CI})\end{array}$ & $p$ value & $\begin{array}{l}\text { Multivariable } \beta \\
\text { coefficient } \\
(95 \% \text { CI })\end{array}$ & $p$ value \\
\hline Sex (female) & $-4.4(-5.8 ;-2.9)$ & $<0.01$ & $-3.9(-5.4 ;-2.6)$ & $<0.01$ \\
\hline \multicolumn{5}{|l|}{ Latitude code ${ }^{\mathrm{a}}$} \\
\hline $1\left(>40^{\circ} \mathrm{S}\right)$ & $-2.7(-5.9 ; 0.5)$ & 0.09 & $-1.4(-4.7 ; 1.8)$ & 0.37 \\
\hline $2\left(31^{\circ}\right.$ to $\left.40^{\circ} \mathrm{S}\right)$ & $-2.3(-4.4 ;-0.3)$ & 0.02 & $-0.9(-3.1 ; 1.3)$ & 0.42 \\
\hline $3\left(21^{\circ}\right.$ to $\left.30^{\circ} \mathrm{S}\right)$ & $-2.9(-5.5 ;-0.5)$ & 0.02 & $-1.5(-4.1 ; 1.1)$ & 0.25 \\
\hline $4\left(11^{\circ}\right.$ to $\left.20^{\circ} \mathrm{S}\right)$ & $-3.3(-6.7 ; 0.1)$ & 0.05 & $-1.2(-4.7 ; 2.4)$ & 0.53 \\
\hline $5\left(1^{\circ}\right.$ to $\left.10^{\circ} \mathrm{S}\right)$ & $-5.1(-7.9 ;-2.2)$ & $<0.01$ & $-3.2(-6.2 ;-0.3)$ & 0.03 \\
\hline $6\left(0^{\circ}\right.$ to $\left.9^{\circ} \mathrm{N}\right)$ & $-3.8(-6.5 ;-1.1)$ & $<0.01$ & $-2.4(-5.2 ; 0.3)$ & 0.08 \\
\hline $7\left(10^{\circ}\right.$ to $\left.19^{\circ} \mathrm{N}\right)$ & $-4.2(-6.4 ;-1.9)$ & $<0.01$ & $-3.3(-5.5 ;-1.0)$ & $<0.01$ \\
\hline $8\left(20^{\circ}\right.$ to $\left.29^{\circ} \mathrm{N}\right)$ & $-8.2(-10.3 ;-6.0)$ & $<0.01$ & $-7.6(-9.7 ;-5.4)$ & $<0.01$ \\
\hline $9\left(30^{\circ}\right.$ to $\left.39^{\circ} \mathrm{N}\right)$ & $-4.9(-7.5 ;-2.4)$ & $<0.01$ & $-4.3(-6.8 ;-1.8)$ & $<0.01$ \\
\hline $10\left(40^{\circ}\right.$ to $\left.49^{\circ} \mathrm{N}\right)$ & $-0.4(-3.2 ; 2.3)$ & 0.8 & $-0.0(-2.7 ; 2.7)$ & 0.99 \\
\hline Cities above the equator & $-1.1(-2.3 ;-0.02)$ & 0.04 & $*$ & \\
\hline \multicolumn{5}{|l|}{ Longitude regions ${ }^{\mathrm{b}}$} \\
\hline Europe, Africa, West Asia ${ }^{c}$ & $1.9(0.1 ; 3.6)$ & 0.04 & $* *$ & \\
\hline Americas $\left(30^{\circ} \mathrm{W}\right.$ to $\left.134^{\circ} \mathrm{W}\right)$ & $-1.6(-3.2 ; 0.07)$ & 0.06 & $* *$ & \\
\hline Western cities $^{\mathrm{d}}$ & $-0.9(-2.0 ; 0.2)$ & 0.10 & $-1.6(-2.9 ;-0.3)$ & 0.01 \\
\hline \multicolumn{5}{|c|}{${ }^{a}$ Group $11\left(>50^{\circ} \mathrm{N}\right)$ is the referent group } \\
\hline \multicolumn{5}{|c|}{${ }^{\mathrm{b}}$ East Asia, Australia, and New Zealand $\left(105^{\circ} \mathrm{E}\right.$ to $\left.180^{\circ} \mathrm{E}\right)$ is the referent group } \\
\hline \multicolumn{5}{|c|}{${ }^{\mathrm{c}}$ Europe, Africa, Western Asia; $29^{\circ} \mathrm{W}$ to $104^{\circ} \mathrm{E}$} \\
\hline \multicolumn{5}{|c|}{${ }^{\mathrm{d}}$ Starting from the Greenwich parallel } \\
\hline \multicolumn{5}{|l|}{ *Nonsignificant in the second step } \\
\hline$* *$ Nonsignificant in the third step & & & & \\
\hline
\end{tabular}

younger age among females; in patients from latitude codes 5 , 7,8 , and 9; and in those from countries in the Western Hemisphere (west of the Greenwich parallel).

Although we found no similar reports with which to compare our results, these are in concert with other studies conducted at regional level. In 2007, our group reported that the mean age of RAO was significantly younger among Mexicans than among Canadians [15], with figures similar to those reported here. Abdel-Nasser et al. [1] reported that Egyptian patients, especially women, had a significantly younger age of RAO than Dutch patients. Studies from India and Pakistan have a higher RA prevalence in the age groups of 25-29 years [24] and 16-29 years [25], respectively. Studies from the USA have found that the incidence of RA varies by geographic coordinates [26, 27].

Therefore, it seems plausible that latitude gradients play a major role in triggering those mechanisms responsible for RA initiation among genetically predisposed subjects. We posit that this happens because of two characteristics that are shared among countries located near the Tropic of Cancer, which may differentiate them from nations at northern latitudes: the developmental status of these countries (developing countries around the Tropic of Cancer versus developed northern nations) and the latitude gradient per se.

Post hoc analysis showed a significant relationship between the age of RAO and countries' HDI, which became even stronger when adjusted for inequality. Developmental status takes into account life expectancy, education, per capita income, and inequality. These variables can in turn act as surrogates for population health, lifestyle, environmental pollutants, and exposure to infections. Therefore, air pollution, local environmental policies, social inequalities, the age of exposure to infections and how they are treated, changes in the microbiome because of infection or seasonal variation in diet [28], oral contraceptive use, age at first pregnancy, and breastfeeding practices may be related to differences between developing and developed countries. For instance, air pollution - a mixture of suspended particulate matter mainly from vehicular traffic, industry, stationary fuel burners, and solid fuel combustion - has recently been found to be associated with RA [29]. A study in Sweden found that the risk of developing RA was increased with exposure to gaseous pollutants $\left(\mathrm{NO}_{2}\right.$ and $\left.\mathrm{SO}_{2}\right)$ in the 10th year before disease onset [30]. Lower socioeconomic status has been associated with RA [31], and there is an increased risk of exposure to atmospheric 
pollution and greater smoking consumption compared with individuals at higher income levels [32,33]. A variable also to consider is oral contraceptive use, which may delay the onset of RA [34] and have a protective effect [35]. Use of oral contraceptives is less common at an early age in developing countries than in developed ones [36]. Having more than one pregnancy, young age at first pregnancy, and breastfeeding patterns are other possible factors [37-39]. A delay in the age of RAO in developed countries may be related to an increased tendency to postpone first pregnancies or a tendency not to breastfeed [40]. Exposure to infections may have a dual effect on the initiation of RA in susceptible individuals. Some infections may produce a protective effect [41, 42], whereas others, such as periodontal disease, may increase the risk of triggering RA [31]. Hence, exposure to specific infectious agents and how they are treated, with consequent changes in the microbiome [43], may be related to socioeconomic status, health care characteristics, and inequality, which may in turn be related to a country's developmental status.

Several of these variables can be modified by nonmedical means that depend more on public health measures than on pharmacologic interventions. If our hypothesis is correct, the age of RAO could be modified to affect fewer years in the lives of RA patients from developing countries, analogous to the decline in infectious diseases during the 19th and 20th centuries before the extended use of antibiotics, thereby reducing disease burden and health care costs [44].

The second characteristic that differentiates countries around the Tropic of Cancer from those at northern latitudes is the gradient of latitudes where countries are located. The incidence and periodicity of RA have been found to be related to increasing geographic latitudes, which determine the magnitude of exposure to variables such as solar cycles, auroral electrojets, extreme ultraviolet radiation, substorms, and magnetic field perturbations [45]. Unfortunately, these variables have only been studied in limited geographic areas over short time spans. Future studies with larger data sets that cover several countries and organized by geomagnetic and geographic coordinates would be necessary, to assess the biologic disturbance and magnitude that these variables may cause [46] on the incidence and age of RAO.

We chose a proof-of-concept study for feasibility reasons; however, this design has inherent limitations such as the fact that chance (random), bias, and confounders cannot be controlled. Our approach to decrease issues of RA ascertainment and selection bias included the recruitment of rheumatologists listed in rheumatology association registers as well as their selfreporting of board certification and that they had patients with RA under their care. Instructions for determining patient age of RAO were clearly stated, and participants were not informed of the primary aim of the study at the time of data collection. The wide standard deviation in the mean age of RAO observed in each data set suggests that participants maintained a typical rheumatology practice. Unfortunately, it was possible to assess intracity consistency in only one third of participating cities, and inconsistencies were found in some of them. Chance is the most viable explanation based on the small sample of patients that we requested of each rheumatologist, the broad $95 \%$ CI of each data set, and the nonsignificance of other variables such as length or type of practice.

Intracountry consistency could be assessed for nearly half of participating countries, but some significant differences were observed. We retrieved the mean age of RAO reported in other studies (referent studies), to gain some insight into how much of our data from these countries are different from those reported previously, although the definitions of age of onset in these referent studies were different from ours. Mean ages of RAO in referent studies from Brazil ( $44.9 \pm 14.5$ years) [47] and Australia (49.6 \pm 11 years) [48] were similar to our data from these countries; we did not find any published data from Ecuador. However, the main limitation of our study lies in the $11(27 \%)$ countries where only one rheumatologist participated. Referent studies from Switzerland (mean age of RAO 51.5 years) [49], Japan (49 years) [50], Kenya (41 \pm 17 years) [51], Nigeria (42 years) [52], Sweden (58 \pm 18 years) [14], Russia (53 years) [53], Colombia (44 \pm 12 years) [54], Burkina Faso (35 years) [55], and Iran (41 \pm 13 years) [56] reported figures similar to ours. We did not find referent studies from Ghana or Panama.

In summary, RA often begins at an early age and its onset varies across latitudes throughout the world. From this observation, it can be hypothesized that countries' developmental status and location influence the age of RAO. These features warrant further studies on the precise magnitude of this phenomenon and the possible causality of diverse factors such as pollution, pregnancy-related patterns, and infection exposures, all adjusted for inequality, as well as atmospheric variables adjusted by geographical and geomagnetic coordinates.

Acknowledgements We thank Graciela S. Alarcon, M.P.H., for assistance with the preparation of an earlier version of the manuscript. We thank Maarten Boers, Ph.D., for providing data. We thank Leopoldo Mendoza-Garcia for artworks.

The members of the GEO-RA Group are as follows:

Universidad Autonoma de Guadalajara, Guadalajara, Mexico Cesar Ramos-Remus

Unidad de Investigacion en Enfermedades Cronico-Degenerativas, Guadalajara, Mexico

Aldo Barajas-Ochoa

Andrea Ramirez-Gomez

Jose D. Castillo-Ortiz

Victor Brambila-Barba

Faculty of Medicine, Dentistry and Health University of Sheffield, Sheffield, UK

Adewale O. Adebajo 
LSU Health Sciences Center, New Orleans, USA Luis R. Espinoza

Hospital General Regional 46, Instituto Mexicano del Seguro Social, Guadalajara, Mexico

Francisco J. Aceves-Avila

Secretaria de Salud Jalisco, Guadalajara, Mexico Jorge M. Sánchez-González

Dr. Benbadis University Hospital, Constantine, Algeria Nadia Boudersa

University of Batna 2, Batna, Algeria Samy Slimani

Ben Aknoun Hospital, University of Algiers, Algiers, Algeria Aicha Ladjouze-Rezig

Centro Traumatológico Bariloche, Bariloche, Argentina Mónica P. Diaz

Sanatorio San Carlos, Bariloche, Argentina Karin I. Kirmayr

Hospital Alemán, Buenos Aires, Argentina Cecilia A. Asnal

Hospital Italiano de Buenos Aires, Instituto Universitario, Escuela de Medicina Hospital Italiano de Buenos Aires y Fundación Dr. Pedro M.

Catoggio para el Progreso de la Reumatología, Buenos Aires, Argentina Luis J. Catoggio

Instituto de Rehabilitación Psicofísica, Buenos Aires, Argentina Gustavo Citera

Hospital Militar Central, Buenos Aires, Argentina Gustavo C. Casado

Hospital Penna, Buenos Aires, Argentina Analia P. Alvarez

Departamento de Medicina Interna, CEMIC, Buenos Aires, Argentina Cecilia N. Pisoni

Hospital Distrito Sanitario N 8: Eva Perón, Formosa, Argentina Emilio Benavente

Centro Fleboestético del Sur, General Roca, Argentina Adriana Lopez-Cabanillas

Hospital Zonal General Roca, General Roca, Argentina Roberto M. Baez

Instituto Cardiovascular de Rosario, Rosario, Argentina Bernardo A. Pons-Estel

Hospital Provincial de Rosario, Rosario, Argentina Mónica P. Sacnún

Sección de Reumatologia y Enfermedades Autoimmunes, Hospital JB Iturraspe, Santa Fe, Argentina

Javier A. Cavallasca

Centro Privado de Rehabilitación, Santa Rosa, Argentina Raúl H. Paniego

Royal Adelaide Hospital and Discipline of Medicine, University of Adelaide, Adelaide, Australia

Susanna M. Proudman

The University of Queensland Diamantina Institute, Princess Alexandra Hospital, Brisbane, Australia

Ranjeny Thomas
Bone \& Joint Institute Royal New Castle Centre and University of Newcastle, Newcastle, Australia

Gabor Major

Georgetown Arthritis, Newcastle, Australia David M. Mathers

Department of Rheumatology, Royal North Shore Hospital, Institute of Bone and Joint Research, Kolling Institute, Sydney, Australia Leslie Schrieber

Department of Rheumatology, Bangabandhu Sheikh Mujib Medical University (BSMMU), Dhaka, Bangladesh

Nazrul Islam

Syed A. Hac

Rheumatology Division, University Hospital Brussels and Free University Brussels, Brussels, Belgium Patrick H. Dessein

Rheuma Clinic and Brazilian Society of Autoimmunity, Porto Alegre, Brazil Carlos A. von Muhlen

Postgraduate School-Pontifica Universidade Católica, and Rheumatology Department at Santa Casa da Misericórdia do Rio de Janeiro General Hospital, Rio de Janeiro, Brazil Washington A. Bianchi

Universidade do Estado do Rio de Janeiro, Rio de Janeiro, Brazil Geraldo da R. Castelar-Pinheiro

Escola Paulista de Medicina, Universidade Federal De Sao Paulo, Sao Paulo, Brazil Daniel Feldman-Pollak

Rheumatology Division, School of Medicine of Jundiai, Sao Paulo, Brazil Waldenise Cossermelli

Hospital das Clinicas-Faculdade de Medicina da Universidade de São Paulo, São Paulo, Brazil Karina R. Bonfiglioli

Serviço de Reumatologia, Hospital do Servidor Público Estadual FranciscoMorato de Oliveira (HSPE-FMO), São Paulo, Brasil Rina D. Giorgi

Centre Hospitalier Universitaire Yalgado Ouedraogo, University of Ouagadougou, Ouagadougou, Burkina Faso Wendlassida J. Zabsonre-Tiendrebeogo

University of Alberta, Edmonton, Canada Anthony S. Russell Lilia Olaru

Ottawa Hospital, Ottawa, Canada Jacob Karsh

University of Concepción, Concepción, Chile Irene H. Castro-Esparza

Hospital Clínico San Borja Arriarán, Santiago, Chile Carlos Fuentealba

Clínica Indisa, Universidad de Chile, Santiago, Chile Sergio Aguilera

Pontificia Universidad Católica de Chile, Santiago, Chile Paula I. Burgos

Hospital del Salvador, Facultad de Medicina Universidad de Chile, and Clínica Alemana, Facultad de Medicina Clínica Alemana-UDD, Santiago, Chile

Oscar Neira 
Department of Rheumatology and Immunology, Beijing University Medical School People's Hospital, Beijing, China

Zhan-guo Li

Department of Medicine \& Therapeutics, the Chinese University of Hong Kong, Hong Kong, China

Lai-Shan Tam

Department of Biomedical Sciences, the City University of Hong

Kong, Hong Kong, China

Mo Y. Mok

Universidad Nacional de Colombia, Bogotá, Colombia Yimy F. Medina

Hospital Luis Vernaza, Guayaquil, Ecuador

Andrés E. Zúñiga-Vera

Mario J. Moreno-Alvarez

Universidad Católica de Guayaquil, Guayaquil, Ecuador Claudia Vera

Hospital de Especialidades Eugenio Espejo, Quito, Ecuador Ivonne Quezada

Clínica Santa Lucia, Quito, Ecuador Iván M. Moreno

Centro de Atención Ambulatoria El Batán (IESS), Quito, Ecuador Wendy Calapaqui

Rheumatology Unit, Cairo University Hospitals, Cairo, Egypt Ghada El-Mardenly

Department of Medicine, Ain Shams University, Cairo, Egypt M. Salah Salama

Rheumatology and Immunology Unit, Department of Internal

Medicine, Faculty of Medicine, Cairo University, Cairo, Egypt

Gaafar Ragab

Kamel Gado

Rheumatology Center, Cairo, Egypt

Tahsin Hadidi

Department of Rheumatology, Helsinki University Hospital and

University of Helsinki, Helsinki, Finland

Marjatta Leirisalo-Repo

Riitta Tuompo

Kanta-Häme Hospital, Riihimäki, Finland Riitta Koivuniemi

INSERM UMR-S938, Faculty of Medicine Pierre \& Marie Curie Paris VI, Paris, France, and Department of Rheumatology, SaintAntoine Hospital, AP-HP, Paris, France Francis Berenbaum

Rheumatology A Department, Cochin Hospital, Paris Descartes University, Paris, France Yannick Allanore

Centre de Rhumatologie, Hôpital Purpan, and Université Paul

Sabatier Toulouse III, Toulouse, France Arnaud Constantin

Department of Rheumatology and Clinical Immunology, Charité University Medicine Berlin (CCM), Berlin, Germany Frank Buttgereit

Division of Rheumatology and Clinical Immunology, Medizinische Klinik und Poliklinik IV, Ludwig Maximilians University, Munich, Germany

Hendrik Schulze-Koops

Myriam Liz
School of Medicine and Dentistry, University of Ghana, Accra, Ghana Dzifa Dey

Instituto Hondureño de Seguridad Social, Tegucigalpa, Honduras Carlos B. Santiago-Pastelín

Hugo D. Alonzo-Borjas

Víctor Cuéllar-Cruz

Institute of Rheumatology and Autoimmune Disorders, Sakra World

Hospital, Bangalore, India

Balebail G. Dharmanand

P.D. Hinduja Hospital and Medical Research Centre, Mumbai, India G.C. Yathish

Mumbai Arthritis Clinic, Mumbai, India Shashank M. Akerkar

Department of Rheumatology, ISIC Superspeciality Hospital and

'A\&R Clinic for Arthritis \& Rheumatism', New Delhi, India Anand N. Malaviya

Shahid Beheshti University of Medical Sciences, Tehran, Iran Arman Ahmadzadeh

Central Clinic, Tokyo, Japan Tomoko Hasunuma

Kenyatta National Hospital, Nairobi, Kenya Benard O. Owino

Facultad de Medicina, Universidad Autónoma de Chihuahua, Chihuahua, Mexico César Pacheco-Tena

Departamento de Medicina, Clínica Hospital ISSSTE, Gómez Palacio, Mexico Aaron Frausto-Arenas

Universidad de Colima, Colima, Mexico Adrián A. De la Madrid-Cernas

Centro Reumatológico de Querétaro, Querétaro, Mexico Román Cardona-Cabrera

Instituto Mexicano del Seguro Social, Hermosillo, Mexico Juan D. Centeno-Valadez

Unidad de Enfermedades Reumáticas y Crónico Degenerativas, Torreón, Mexico Isaura M. Rodríguez-Torres

National Center for Rheumatic Diseases, Kathmandu, Nepal Binit Vaidya

Kathmandu, Nepal Arun K. Gupta

Department of Medicine, University of Otago Wellington, Wellington, New Zealand Andrew A. Harrison

Department of Medicine and Department of Pathology and Molecular Medicine, University of Otago Wellington, Wellington, New Zealand Rebecca Grainger

Nnamdi Azikiwe University Teaching Hospital, Nnewi, Nigeria Henry M. Nwankwo

Department of Rheumatology, Hospital for Rheumatic Diseases,

Haugesund, Haugesund, Norway Andreas P. Diamantopoulos Elisabeth Mæland 
UiT the Arctic University of Norway and Finnmarkssykehuset i Kirkenes, Kirkenes, Norway

Emilio Besada

Hospital Santo Tomas, Panama, Panama

Luis Gorriz

Hospital de Clínicas, Universidad Nacional de Asunción, Asunción,

Paraguay

Margarita Duarte

Sonia Cabrera-Villalba

Sanatorio Santa Clara, Asunción, Paraguay

Maria T. Romero-de Albrecht

Hospital Carlos Alcántara B, Lima, Peru

Augusto García-Poma

Hospital Nacional Edgardo Rebagliati Martins, EsSalud, Lima Peru, and Universidad Nacional Mayor de San Marcos, Lima, Peru María I. Segami

Hospital Nacional Edgardo Rebagliati Martins, EsSalud, Lima, Peru María P. Ramos

Wilkerson Pérez-Medina

Dr. Pablo O. Torre Memorial Hospital, Manila, Philippines Maria L. Dianongco

St Luke's Medical Center, Manila, Philippines Juan J. Lichauco

St. Luke's Medical Center BGC; Manila Doctors Hospital; University of the Philippines-Philippine General Hospital, Manila, Philippines Geraldine Z. Racaza

University of Santo Tomas Hospital, Manila, Philippines Sandra V. Navarra

Tito P. Torralba

University of the Philippines-Philippine General Hospital, Manila, Philippines

Bernadette H. Manapat-Reyes

Ester G. Penserga

Hamad Medical Corporation, Doha, Qatar

Mohammed Hammoudeh

Samar Al-Emadi

Privat out-patients' clinic “Agat”, Egorievsk, Russia Anna G. Botchkova

Department of Medicine, Rheumatology Unit, King Fahd Hospital, Jeddah, Saudi Arabia

Sabri H. AlSaeedi

Alzaidi Chair of Research in Rheumatic Diseases-Umm Alqura University, Makkah, Saudi Arabia, and Department of Medicine,

Dr. Soliman Fakeeh Hospital, Jeddah, Saudi Arabia Hani Almoallim

King Saud University, Riyadh, Saudi Arabia Hussein F. Al-Arfaj

Koh Wei Howe Arthritis \& Rheumatism Medical Clinic, Singapore, Singapore Wei H. Koh

Department of Rheumatology \& Immunology, Singapore General Hospital, and Duke-NUS Graduate Medical School, Singapore, Singapore Ying Y. Leung
Tygerberg Hospital and Stellenbosch University, Bellville, South Africa

David A. Whitelaw

Department of Medicine, Division of Rheumatology, University of Cape Town and Groote Schuur Hospital, Cape Town, South Africa Bridget Hodkinson

Hospital Universitari Sagrat Cor, Barcelona, Spain Javier García-Miguel

Rheumatology Unit. IDC-Salud, Clínica del Pilar, Barcelona, Spain Juan C. Duro

Department of Rheumatology, Hospital Universitario La Paz, Madrid, Spain

Emilio Martin-Mola

Hospital Central de la Defensa Gómez Ulla, Madrid, Spain María Ahijón-Lana

Hospital Universitario Puerta de Hierro, Majadahonda, Spain José L. Andreu

University Hospitals of Geneva, Geneva, Switzerland Axel Finckh

Deshiré Alpízar-Rodríguez

Division of Rheumatology, Department of Medicine, Faculty of Medicine, Chulalongkorn University, Bangkok, Thailand Manathip Osiri

Division of Rheumatology, Department of Internal Medicine, Faculty of Medicine, Chiang Mai University, Chiang Mai, Thailand

Nuntana Kasitanon

Worawit Louthrenoo

Amsterdam Rheumatology and Immunology Center (ARC), Amsterdam, The Netherlands Ronald F. van Vollenhoven

Amsterdam Rheumatology and Immunology Center (ARC), Department of Clinical Immunology \& Rheumatology, Academic Medical Center, Amsterdam, The Netherlands Niek de Vries

Amsterdam Rheumatology and Immunology Center (ARC), Reade Institute, Amsterdam, The Netherlands Christiaan van Denderen Martjin Gerritsen

VieCuri Medical Centre, Venlo, and Scientific Institute for Quality of Healthcare, Radboud University Medical Center, Nijmegen, The Netherlands

Tim L. Jansen

Department of Rheumatology, Bernhoven, Uden, The Netherlands Piet van Riel

Universidad Centroccidental Lisandro Alvarado, Clínica Razetti de

Barquisimeto, Barquisimeto, Venezuela Concepción M. Núñez-Sotelo

Servicio de Reumatología, Hospital Vargas, Caracas, Venezuela Sol Villegas-Morales

Compliance with ethical standards

Disclosures None.

Funding This study had no funding from any private, public, or government institutions. 


\section{References}

1. Abdel-Nasser AM, Rasker JJ, Valkenburg HA (1997) Epidemiological and clinical aspects relating to the variability of rheumatoid arthritis. Semin Arthritis Rheum 27(2):123-140

2. Alamanos Y, Drosos AA (2005) Epidemiology of adult rheumatoid arthritis. Autoimmun Rev 4(3):130-136. doi:10.1016/j. autrev.2004.09.002

3. Alamanos Y, Voulgari PV, Drosos AA (2006) Incidence and prevalence of rheumatoid arthritis, based on the 1987 American College of Rheumatology criteria: a systematic review. Semin Arthritis Rheum 36(3):182-188. doi:10.1016/j.semarthrit.2006.08.006

4. Doran MF, Pond GR, Crowson CS, O'Fallon WM, Gabriel SE (2002) Trends in incidence and mortality in rheumatoid arthritis in Rochester, Minnesota, over a forty-year period. Arthritis Rheum 46(3):625-631. doi:10.1002/art.509

5. Jacobsson LT, Hanson RL, Knowler WC, Pillemer S, Pettitt DJ, McCance DR, Bennett PH (1994) Decreasing incidence and prevalence of rheumatoid arthritis in Pima Indians over a twenty-fiveyear period. Arthritis Rheum 37(8):1158-1165

6. Myasoedova E, Crowson CS, Kremers HM, Therneau TM, Gabriel SE (2010) Is the incidence of rheumatoid arthritis rising?: results from Olmsted County, Minnesota, 1955-2007. Arthritis Rheum 62(6):1576-1582. doi:10.1002/art.27425

7. Buchanan WW (1994) Rheumatoid arthritis: another New World disease? Semin Arthritis Rheum 23(5):289-294

8. MacGregor AJ, Snieder H, Rigby AS, Koskenvuo M, Kaprio J, Aho K, Silman AJ (2000) Characterizing the quantitative genetic contribution to rheumatoid arthritis using data from twins. Arthritis Rheum 43(1):3037. doi:10.1002/1529-0131(200001)43:1<30::AID-ANR5>3.0.CO;2-B

9. Seldin MF, Amos CI, Ward R, Gregersen PK (1999) The genetics revolution and the assault on rheumatoid arthritis. Arthritis Rheum 42(6):1071-1079. doi:10.1002/1529-0131(199906)42:6<1071::AIDANR1>3.0.CO;2-8

10. Vyse TJ, Todd JA, Kotzin BL (1998) Non-MHC genetic contribution to autoimmune diseases. In: Rose NR, Mackay IR (eds) The autoimmune diseases, 3rd. edn., San Diego, pp 85-118.

11. Wolfe F, Cathey MA (1991) The assessment and prediction of functional disability in rheumatoid arthritis. J Rheumatol 18(9):1298-1306

12. Cooper GS, Stroehla BC (2003) The epidemiology of autoimmune diseases. Autoimmun Rev 2(3):119-125

13. Tiippana-Kinnunen $\mathrm{T}$, Kautiainen H, Paimela L, LeirisaloRepo M (2013) Co-morbidities in Finnish patients with rheumatoid arthritis: 15-year follow-up. Scand J Rheumatol 42(6):451-456. doi:10.3109/03009742.2013.790073

14. Waldenlind K, Eriksson JK, Grewin B, Askling J (2014) Validation of the rheumatoid arthritis diagnosis in the Swedish National Patient Register: a cohort study from Stockholm County. BMC Musculoskelet Disord 15:432. doi:10.1186/1471-2474-15-432

15. Ramos-Remus C, Sierra-Jimenez G, Skeith K, Aceves-Avila FJ, Russell AS, Offer R, Olguin-Redes JE, Homik J, Sanchez L, Sanchez-Ortiz A, Navarro-Cano G (2007) Latitude gradient influences the age of onset in rheumatoid arthritis patients. Clin Rheumatol 26(10):1725-1728. doi:10.1007/s10067-007-0666-2

16. Badsha H, Kong KO, Tak PP (2008) Rheumatoid arthritis in the United Arab Emirates. Clin Rheumatol 27(6):739-742. doi:10.1007/s10067-007-0782-z

17. Shapira Y, Agmon-Levin N, Shoenfeld Y (2010) Defining and analyzing geoepidemiology and human autoimmunity. J Autoimmun 34(3):J168-J177. doi:10.1016/j.jaut.2009.11.018

18. Arnett FC, Edworthy SM, Bloch DA, McShane DJ, Fries JF, Cooper NS, Healey LA, Kaplan SR, Liang MH, Luthra HS et al (1988) The American Rheumatism Association 1987 revised criteria for the classification of rheumatoid arthritis. Arthritis Rheum 31(3):315-324
19. United Nations Development Programme (2015). Human development reports. http://hdr.undp.org/en/data. Accessed 9 May 2016

20. Helmick CG, Felson DT, Lawrence RC, Gabriel S, Hirsch R, Kwoh CK, Liang MH, Kremers HM, Mayes MD, Merkel PA, Pillemer SR, Reveille JD, Stone JH (2008) Estimates of the prevalence of arthritis and other rheumatic conditions in the United States. Part I Arthritis Rheum 58(1):15-25. doi:10.1002/art.23177

21. Kaipiainen-Seppanen O, Aho K, Isomaki H, Laakso M (1996) Shift in the incidence of rheumatoid arthritis toward elderly patients in Finland during 1975-1990. Clin Exp Rheumatol 14(5):537-542

22. Shichikawa K, Inoue K, Hirota S, Maeda A, Ota H, Kimura M, Ushiyama T, Tsujimoto M (1999) Changes in the incidence and prevalence of rheumatoid arthritis in Kamitonda, Wakayama, Japan, 1965-1996. Ann Rheum Dis 58(12):751-756

23. Hochberg MC (1990) Changes in the incidence and prevalence of rheumatoid arthritis in England and Wales, 1970-1982. Semin Arthritis Rheum 19(5):294-302

24. Malaviya AN, Kapoor SK, Singh RR, Kumar A, Pande I (1993) Prevalence of rheumatoid arthritis in the adult Indian population. Rheumatol Int 13(4):131-134

25. Alam SM, Kidwai AA, Jafri SR, Qureshi BM, Sami A, Qureshi HH, Mirza H (2011) Epidemiology of rheumatoid arthritis in a tertiary care unit, Karachi, Pakistan. J Pak Med Assoc 61(2):123126

26. Costenbader KH, Chang SC, Laden F, Puett R, Karlson EW (2008) Geographic variation in rheumatoid arthritis incidence among women in the United States. Arch Intern Med 168(15):1664 1670. doi:10.1001/archinte.168.15.1664

27. Vieira VM, Hart JE, Webster TF, Weinberg J, Puett R, Laden F, Costenbader KH, Karlson EW (2010) Association between residences in U.S. northern latitudes and rheumatoid arthritis: a spatial analysis of the Nurses' Health Study. Environ Health Perspect 118(7):957-961. doi:10.1289/ehp.0901861

28. Davenport ER, Mizrahi-Man O, Michelini K, Barreiro LB, Ober C, Gilad Y (2014) Seasonal variation in human gut microbiome composition. PLoS One 9(3):e90731. doi:10.1371/journal. pone. 0090731

29. Essouma M, Noubiap JJ (2015) Is air pollution a risk factor for rheumatoid arthritis? J Inflamm (Lond) 12:48. doi:10.1186/s12950015-0092-1

30. Hart JE, Kallberg H, Laden F, Bellander T, Costenbader KH, Holmqvist M, Klareskog L, Alfredsson L, Karlson EW (2013) Ambient air pollution exposures and risk of rheumatoid arthritis: results from the Swedish EIRA case-control study. Ann Rheum Dis 72(6):888-894. doi:10.1136/annrheumdis-2012-201587

31. Tobon GJ, Youinou P, Saraux A (2010) The environment, geoepidemiology, and autoimmune disease: rheumatoid arthritis. J Autoimmun 35(1):10-14. doi:10.1016/j.jaut.2009.12.009

32. Deguen S, Zmirou-Navier D (2010) Social inequalities resulting from health risks related to ambient air quality - a European review. Eur J Pub Health 20(1):27-35. doi:10.1093/eurpub/ckp220

33. Eriksen M, Mackay J, Schluger N, Gomeshtapeh FI, Drope J (2015) The tobacco atlas. http://www.tobaccoatlas.org/topic/cigarette-useglobally. Accessed 23 Jun 2016

34. Spector TD, Hochberg MC (1990) The protective effect of the oral contraceptive pill on rheumatoid arthritis: an overview of the analytical epidemiological studies using meta-analysis. J. Clin Epidemiol 43(11):1221-1230

35. Hazes JM, van Zeben D (1991) Oral contraception and its possible protection against rheumatoid arthritis. Ann Rheum Dis 50(2):72-74

36. Darroch JE, Singh S (2013) Trends in contraceptive need and use in developing countries in 2003, 2008, and 2012: an analysis of national surveys. Lancet 381(9879):1756-1762. doi:10.1016/S01406736(13)60597-8 
37. Alpízar-Rodríguez D, Pluchino N, Canny G, Gabay C, Finckh A (2016) The role of female hormonal factors in the development of rheumatoid arthritis. Rheumatology (Oxford). doi:10.1093/rheumatology/kew318

38. Brennan P, Silman A (1994) Breast-feeding and the onset of rheumatoid arthritis. Arthritis Rheum 37(6):808-813

39. Chen H, Wang J, Zhou W, Yin H, Wang M (2015) Breastfeeding and risk of rheumatoid arthritis: a systematic review and metaanalysis. J Rheumatol 42(9):1563-1569. doi:10.3899/jrheum.150195

40. Cai X, Wardlaw T, Brown DW (2012) Global trends in exclusive breastfeeding. Int Breastfeed J 7(1):12. doi:10.1186/1746-4358-7-12

41. Sandberg ME, Bengtsson C, Klareskog L, Alfredsson L, Saevarsdottir S (2015) Recent infections are associated with decreased risk of rheumatoid arthritis: a population-based case-control study. Ann Rheum Dis 74(5):904-907. doi:10.1136/annrheumdis2014-206493

42. Pearce EJ, Caspar P, Grzych JM, Lewis FA, Sher A (1991) Downregulation of Th1 cytokine production accompanies induction of Th2 responses by a parasitic helminth, Schistosoma mansoni. J Exp Med 173(1):159-166

43. Scher JU, Abramson SB (2011) The microbiome and rheumatoid arthritis. Nat Rev Rheumatol 7(10):569-578. doi:10.1038/nrrheum.2011.121

44. McKeown T. El papel de la medicina. ¿Sueño, espejismo o realidad? Siglo XXI editors S.A. México 1982

45. Wing S, Rider LG, Johnson JR, Miller FW, Matteson EL, Crowson CS, Gabriel SE (2015) Do solar cycles influence giant cell arteritis and rheumatoid arthritis incidence? BMJ Open 5(5):e006636. doi:10.1136/bmjopen-2014-006636

46. Palmer SJ, Rycroft MJ, Cermack M (2006) Solar and geomagnetic activity, extremely low frequency magnetic and electric fields and human health at Earth's surface. Surv Geophys 27:39. doi:10.1007/s10712-0069010-7

47. da Mota LM, Laurindo IM, dos Santos Neto LL (2010) Demographic and clinical characteristics of a cohort of patients with early rheumatoid arthritis. Rev Bras Reumatol 50(3):235-248

48. Littlejohn G, Roberts L, Arnold M, Bird P, Burnet S, de Jager J, Griffiths H, Nicholls D, Scott J, Zochling J, Tymms KE (2013) A multi-center, observational study shows high proportion of Australian rheumatoid arthritis patients have inadequate disease control. Int J Rheum Dis 16(5):532-538. doi:10.1111/1756-185 X.12163

49. Moller B, Pruijm M, Adler S, Scherer A, Villiger PM, Finckh A (2015) Chronic NSAID use and long-term decline of renal function in a prospective rheumatoid arthritis cohort study. Ann Rheum Dis 74(4):718-723. doi:10.1136/annrheumdis-2013-204078

50. Kanazawa T, Nishino J, Tohma S, Tanaka S (2013) Analysis of the affected joints in rheumatoid arthritis patients in a large Japanese cohort. Mod Rheumatol 23(1):44-49. doi:10.1007/s10165-0120636-7

51. Owino BO, Oyoo GO, Otieno CF (2009) Socio-demographic and clinical aspects of rheumatoid arthritis. East Afr Med J 86(5):204-211

52. Adelowo OO, Ojo O, Oduenyi I, Okwara CC (2010) Rheumatoid arthritis among Nigerians: the first 200 patients from a rheumatology clinic. Clin Rheumatol 29(6):593-597. doi:10.1007/s10067-009$1355-0$

53. Maslyanskiy A, Lazareva N, Olinek P, Schierack P, Hentschel C, Cuccato J, Bogdanos DP, Lapin SV, Roggenbuck D (2014) AntihnRNP B1 (RA33) autoantibodies are associated with the clinical phenotype in Russian patients with rheumatoid arthritis and systemic sclerosis. J Immunol Res 2014:516593. doi:10.1155/2014/516593

54. Rojas-Villarraga A, Bayona J, Zuluaga N, Mejia S, Hincapie ME, Anaya JM (2009) The impact of rheumatoid foot on disability in Colombian patients with rheumatoid arthritis. BMC Musculoskelet Disord 10:67. doi:10.1186/1471-2474-10-67

55. Ouedraogo DD, Singbo J, Diallo O, Sawadogo SA, Tieno H, Drabo YJ (2011) Rheumatoid arthritis in Burkina Faso: clinical and serological profiles. Clin Rheumatol 30(12):16171621. doi:10.1007/s10067-011-1831-1

56. Arshadi D, Nikbin B, Shakiba Y, Kiani A, Jamshidi AR, Boroushaki MT (2013) Plasma level of neopterin as a marker of disease activity in treated rheumatoid arthritis patients: association with gender, disease activity and anti-CCP antibody. Int Immunopharmacol 17(3): 763-767. doi:10.1016/j.intimp.2013.08.022 